\title{
PENGARUH STRUKTUR KEPEMILIKAN DAN UKURAN (SIZE) PERBANKAN TERHADAP KINERJA PERBANKAN 2009-2014
}

\author{
Henny Ritha \\ Perbanas Institute \\ Email: henritz32@gmail.com
}

\begin{abstract}
Abstrak. Struktur kepemilikan dan ukuran merupakan bagian penting bagi kelangsungan jangka panjang dunia perbankan, keduanya dapat mempengaruhi kualitas manajer (agen) dalam mengelola suatu bank, dan mendorong pemegang saham (prinsipal) untuk mengawasi kegiatan operasional perbankan demi peningkatan kinerja perbankan. Tujuan penelitian ini adalah untuk menganalisis pengaruh struktur kepemilikan dan ukuran bank terhadap kinerja perbankan.Variabel struktur kepemilikan terdiri dari kepemilikan institusional dan kepemilikan manajerial serta Size sebagai variabel independen dengan Return On Equity (ROE) sebagai proksi dalam penilaian kinerja. Penelitian ini menggunakan sampel yang terdiri dari 6 perbankan yang terdaftar di Bursa Efek Indonesia 2009-2014. Teknik analisis menggunakan analisis regresi data panel dan diperoleh pendekatan Common Effect sebagai model terbaik untuk mengestimasi model regresi data panel. Hasil penelitian membuktikan struktur kepemilikan manajerial dan ukuran perbankan berpengaruh signifikan terhadap kinerja perbankan, sedangkan struktur kepemilikan institusional tidak berpengaruh terhadap kinerja perbankan. Secara simultan, ketiga variabel berpengaruh signifikan dan memberikan kontribusi sebesar 63,07 persen terhadap kinerja perbankan di Bursa Efek Indonesia 2009-2014, sedangkan sisanya 36,93 persen dipengaruhi oleh variabel lain. Peneliti menyarankan untuk menambah periode penelitian dan memperluas kriteria sampel serta menambah variabel struktur kepemilikan lainnya seperti kepemilikan asing, pemerintah dan masyarakat serta menambah variabel Price Earning Ratio (PER) sebagai proksi kinerja perbankan.
\end{abstract}

Kata kunci: Kepemilikan institusional, kepemilikan manajerial, ukuran (size) dan kinerja perbankan.

Abstract. The ownership structure and size is an important part of long-term survival of banking industry, both of which can affect the quality of manager (agent) to manage a bank, and encourage shareholders (principals) to manage banking operations in order to improve the performance of the banking system.This study is conducted to analyze the effect of Ownership Structure and size of banks on banks performance. Both Ownership structure which is represented by Institutional Ownership and Managerial Ownership and.size are independend variables, with Return On Equity is used as a proxy for performance valuation. This study used 6 samples of banks listed in Indonesian Stock Exchange for the period 2009-2014. Technique analysis used panel data regression analysis with Microsoft Excel 2003 data processing and Eviews.8. From the results of the panel data processing, the Common Effect Model approach is obtained as the best model for estimating panel data regression model. The research proves that managerial ownership and banks size have significant impact on banks performance, meanwhile institutional ownership has no significant impact on banks performance. Simultaneously, the three variables have a significant effect and contributed 63.07 percent to the banks performance in Indonesian Stock Exchange from 2009 to 2014, meanwhile the remaining 36,93 percent is influenced by other variables.Researcher suggests prolonging the research period, extending the sample criteria and increasing the ownership structure of foreign ownership, the government and society as well as adding the variable of Price Earning Ratio (PER) as a proxy for banking performance.

Keywords: Institutional ownership, managerial ownership, size,banking performance. 


\section{TRANSPARANSI}

Jurnal Ilmiah Ilmu Administrasi

ISSN 2085-1162

\section{PENDAHULUAN}

Konsep struktur kepemilikan merupakan subjek penting dari tata kelola perusahaan atau perbankan. Prinsip Tata Kelola Perusahaan yang sehat adalah fondasi yang menumbuhkan kepercayaan para investor dan pemberi pinjaman, sedangkan peran tata kelola perusahaan dapat sebagai sarana untuk menarik para investor institusi.

Fenomena yang sering muncul dari tata kelola perusahaan yang baik adalah pengaruh struktur kepemilikan saham yang terkait dengan kinerja perusahaan, salah satu disebabkan adanya perbedaan kepentingan antara manajemen dan pemegang saham. Perbedaan ini menyebabkan konflik keagenan (Agency conflict). Perbedaan kepentingan tersebut terjadi karena manajer lebih mengutamakan kepentingan pribadinya, sebaliknya pemegang saham tidak menyukai perilaku tersebut karena yang dilakukan manajer akan menambah biaya (Agency cost) bagi perusahaan dan menyebabkan penurunan keuntungan perusahaan dan dividen yang diterima pemegang saham (Haruman, 2008). Selain itu manajer lebih memilih memaksimalkan kebutuhan pribadinya dari pada meningkatkan nilai pemegang saham (Moshe dan Khan dalam Al-Matari, 2013)

Adanya perbedaan kepentingan tersebut telah memunculkan teori keagenan (Agency Theory) yang menjelaskan bahwa pemilik perusahaan sebaiknya menyerahkan pengelolaan perusahaan kepada agen profesional (manajemen) agar kegiatan perusahaan dapat berjalan secara efisien dan efektif. Manajemen perusahaan harus berusaha menghemat biaya dan mengutamakan kepentingan pemegang saham (prinsipal), namun praktiknya manajemen bekerja tidak dengan harapan prinsipalnya dan cenderung menyalahgunakan kewenangan yang diberikan. Perilaku manajemen yang mengutamakan kepentingan diri sendiri akan berakibat menurunnya kepercayaan pemegang saham atas return yang diterima dan dapat menurunkan kinerja perusahaan.
Volume VIII, Nomor 02, September 2016

Upaya menghindari agency conflict adalah dengan memberikan kesempatan kepada manajemen untuk memiliki proporsi kepemilikan saham, sehingga manajemen akan mempertimbangkan kepentingannya sebagai pemegang saham dan meningkatkan kinerja perusahaan. Morck, Shleifer dan Vishny (1988) menjelaskan efek kepemilikan manajerial atas kinerja saham bergantung pada tingkat kepemilikan manajer. Peningkatan kepemilikan manajerial memfasilitasi manajer untuk mengendalikan perusahaan, dan menjaga kepentingan manajer dan investor luar. Ketika kepemilikan manajerial rendah, maka insentif kemungkinan terjadinya oportunistik manajemen akan meningkat dan cenderung mendorong manajer mencari sumber pendanaan yang lebih besar untuk mendanai konsumsinya (Jensen dan Meckling, 1976). Besar kecilnya kepemilikan saham manajerial dalam perusahaan mengindikasikan adanya kesamaan kepentingan manajemen dengan pemegang saham, sehingga permasalahan keagenan diasumsikan akan hilang apabila seorang manajer adalah sekaligus seorang pemilik (Munthe, 2012). Sebagai pemilik, peningkatan proporsi saham yang dimiliki manajer akan mengurangi tindakan manajer mengkonsumsi penghasilan tambahan (perquisities) yang berlebihan, sebagaimana dijelaskan Jensen dan Meckling (1976) dalam Agency Cost of Equity. Hasil penelitian Ardianingsih dan Ardiyani (2010), Munthe (2012) menunjukan kepemilikan manajerial berpengaruh signifikan terhadap kinerja perusahaan sedangkan Wahla et al, (2012) menegaskan kepemilikan manajerial memiliki dampak yang signifikan terhadap kinerja perusahaan, dengan tetap melihat leverage di pasar ekuitas. Hasil berbeda dikaji oleh Puspito (2011), Wiranata dan Nugrahanti (2013).

Disisi lain, teori keagenan menimbulkan masalah struktur kepemilikan dan kepemilikan institusional. Investor institusional lebih efektif dalam memonitor kinerja manajemen perusahaan dan mempunyai kewenangan untuk menyeleksi manajer yang berkualitas yang diharapkan dapat memberikan kinerja yang superior. Kepemilikan institusional dapat 
Henny Ritha, Effect of Cash Dividends, Retained Earnings, Earning per Share....

meminimalkan konflik keagenan (agency cost) dengan memonitor kinerja manajemen bahkan mengambil kendali perusahaan itu sendiri (Admati et al., Huddart dan Maug dalam AlNajjar, 2010).

Signifikansi kepemilikan institusional sebagai perangkat monitoring ditekankan melalui investasi mereka yang cukup besar. Semakin tinggi kepemilikan institusi, maka semakin tinggi kinerja saham perusahaan. Apabila institusional merasa tidak puas akan kinerja manajerial, maka mereka akan menjual sahamnya ke pasar modal. Fazlzadeh et al,. (2011) menegaskan kinerja perusahaan akan membaik jika terdapat beberapa pemegang saham institusional berbeda yang memiliki perusahaan, karena mekanisme kontrol dari pihak institusi akan menghindari konflik manajer dan pemegang saham dominan. Hasil penelitiannya terhadap kinerja 137 perusahaan yang terdaftar di bursa saham Teheran 20012006, menunjukan kepemilikan institusional berpengaruh positif terhadap kinerja perusahaaan.

Besar kecilnya ukuran perusahaan (size) dapat dilihat dari besarnya tingkat penjualan, jumlah ekuitas atau jumlah aktiva yang dimiliki perusahaan beserta kapitalisasi pasar sahamnya (Kristianto, 2010). Umumnya perusahaan terkenal memiliki akses informasi yang mudah di pasar modal, hal ini berarti perusahaan besar mempunyai fleksibilitas dalam memperoleh dana dan besarnya total aktiva yang menarik perhatian investor membuat kinerja manajemen lebih mudah dipantau serta memacu manajemen lebih profesional dan terus berusaha meningkatkan kinerja perusahaannya (Mirawati, 2013).

Perusahaan besar lebih mampu meminimalkan risiko investasi, sehingga terhindar dari kesulitan keuangan dan risiko kebangkrutan Hal ini menjadikan perusahaan besar lebih menarik bagi investor institusional. Semakin besar ukuran perusahaan, semakin besar jumlah modal yang dibutuhkan investor untuk memiliki saham perusahaan. Dengan dana yang lebih besar membuat peluang lebih besar untuk mencapai tingkat pertumbuhan, sehingga kinerja perusahaan meningkat.

Penelitian mengenai struktur kepemilikan oleh Munthe (2012), Wahla (2012) serta Ardianingsih dan Ardiyani (2010) menemukan bahwa kepemilikan manajerial, kepemilikan institusional, risiko return saham, dan ukuran perusahaan mempunyai pengaruh positif dan signifikan terhadap kinerja perusahaan, sedangkan struktur kepemilikan manajerial dan struktur kepemilikan institusional tidak berpengaruh terhadap kinerja perusahaan telah dibuktikan oleh Wiranata dan Nugrahanti (2013), Mirawati (2013) dan Puspito (2011). Menurut teori keagenan dan berbagai teori lainnya hubungan struktur kepemilikan dan kinerja perusahaan seharusnya positif.

Adanya beberapa perbedaan temuan sebelumnya menjadikan penelitian ini menarik untuk diteliti. Perbedaan penelitian ini dengan penelitian sebelumnya adalah penelitian ini hanya memisahkan struktur kepemilikan yang terdiri dari kepemilikan manajerial dan kepemilikan institusional. Dipilihnya industri perbankan yang terdaftar di Bursa Efek Indonesia 2009-2014 sebagai sampel penelitian ini, karena perbankan memiliki karakteristik yang berbeda dibandingkan perusahaan industri pada umumnya. Manfaat penelitian bagi investor yaitu dapat memberikan rujukan untuk mengambil keputusan yang tepat dalam berinvestasi pada perusahaan yang struktur kepemilikannya dapat meningkatkan kinerja perbankan, dan bagi emiten tentunya memberikan masukan dalam mengambil keputusan dalam meningkatkan kinerja perbankan.

\section{Teori Keagenan}

Hubungan keagenan terjadi ketika pemegang saham (principal) mempercayakan perusahaan untuk dikendalikan oleh manajemen (agent) dan bekerja atas nama principal. Konflik yang timbul dalam hubungan keagenan didorong oleh keunggulan agent memiliki informasi keuangan yang lebih lengkap, serta kemampuan principal memanfaatkan kekuasaannya, sehingga principal dan agent cenderung mengutamakan kepentingan pribadi atau kelompoknya sendiri dalam bertindak. Teori keagenan mengimplikasikan adanya asimetri informasi antara manajer sebagai agent dan pemegang saham sebagai principal (Mirawati, 2013). Asimetri ini muncul ketika manajer lebih mengetahui informasi internal dan prospek 


\section{TRANSPARANSI}

Jurnal Ilmiah Ilmu Administrasi

ISSN 2085-1162

perusahaan di masa yang akan datang. Manajer mempunyai informasi lebih banyak dan cepat dibandingkan pihak eksternal, sehingga dari informasi yang diketahui manajer mempunyai kesempatan untuk memanipulasi pelaporan keuangan demi kepentingannya sendiri (Setiawan, dkk., 2006). Masalah keagenan muncul ketika manajer memiliki kurang dari $100 \%$ saham aset perusahaan, hal ini disebabkan adanya keengganan manajer bertindak demi memaksimalkan nilai perusahaan (Iavorskyi, 2013). Pemegang saham bertujuan memaksimumkan kekayaannya dengan mengacu pada nilai sekarang arus kas investasi perusahaan, sedangkan manajer bertujuan meningkatkan pertumbuhan dan ukuran perusahaan. Tindakan membatasi perilaku agent yang menyimpang dapat dilakukan principal dengan menyediakan biaya pengawasan (Monitoring cost) yang merupakan bagian dari agent cost atau biaya untuk mengawasi perilaku agent agar mereka bertindak sesuai kepentingan principal dan melaporkan segala aktivitas manajemen secara akurat (Jensen and Meckling, 1976).

\section{KAJIAN PUSTAKA}

\section{Struktur Kepemilikan}

Perbedaan pendapat dalam teori keagenan telah menimbulkan pemisahan pengelolaan dan kepemilikan saham. Sebuah perusahaan dapat dimiliki oleh masyarakat, pemerintah, pihak asing, maupun orang dalam perusahaan atau manajer. Munthe (2012) menyatakan pendistribusian struktur kepemilikan saham berdampak pada motif tiap pemegang saham dalam investasinya. Investor saham jangka pendek mengutamakan gain atas penjualan saham, sedangkan investor jangka panjang lebih meningkatkan kesejahteraan melalui tujuan perusahaan, dan membuat keputusan secara periodik tentang komitmennya untuk bertahan pada pengembangan usaha. Struktur kepemilikan juga akan mempengaruhi perilaku perusahaan karena adanya pergantian kepemimpinan akan merubah performansi perusahaan (Setiawan, dkk, 2006). Beberapa peneliti seperti Wahla et al., 2012 dan Chung et al., 2010 menyebutkan struktur kepemilikan dinilai sebagai suatu cara mengurangi keterbukaan informasi yang tidak seimbang di pasar modal. Banyak studi yang menyelidiki hubungan struktur kepemilikan dengan kinerja perusahaan karena penting peranan struktur kepemilikan dalam menarik investor lokal maupun asing dalam memastikan investasi masa depan. Morck et al. (1988) meneliti hubungan sturktur kepemilikan dan kinerja di pasar modal Jepang. Hasilnya menunjukan nilai pasar meningkat ketika struktur kepemilikan meningkat (manajemen dan pemegang saham mayoritas). Struktur kepemilikan memberikan nilai dan peran positif untuk mendorong kinerja perusahaan melalui penawaran informasi yang transparan (AlMatari et al., 2013). Namun berbeda dengan Demsetz dan Villalonga (2001) yang menemukan tidak adanya hubungan yang signifikan antara struktur kepemilikan dan kinerja perusahaaan.

\section{Struktur Kepemilikan Instituional}

Kepemilikan institusional merupakan jumlah saham yang ditanamkan oleh institusi pada perusahaan (Munthe, 2012 dan Kristianto, 2010). Pemegang saham institusional dapat memerintahkan direksi agar melindungi mereka dan meningkatkan tata kelola perusahaan (AlMatari, 2013). Dengan keunggulan memilih direksi dalam kursi dewan memungkinkan pemegang saham mengawasi perusahaan atas nama mereka. Pengawasan terhadap perusahaan didorong oleh perilaku direksi yang cenderung memberikan kesetiaannya kepada pejabat perusahaan yang bertentangan kepentingan dengan pemegang saham. Investor institusi lebih efektif dalam memonitor kinerja manajemen perusahaan karena memiliki akses informasi yang luas, selain itu investor institusi cenderung lebih memilih saham dengan likuiditas pasar yang tinggi dan volatilitas return yang lebih rendah (Chung and Zhang, 2011). Investor institusi yang besar mempunyai insentif yang signifikan dalam memonitor kinerja manajemen perusahaan. Signifikansi 


\section{Henny Ritha, Effect of Cash Dividends, Retained Earnings, Earning per Share....}

institutional ownership sebagai agen pengawas ditekankan melalui investasi institusional yang cukup besar dalam pasar modal (Al-Najjar, 2010). Apabila pihak institusi merasa tidak puas atas kinerja manajemen, maka pihak institusi akan menjual sahamnya ke pasar. Keberadaan investor institusional dianggap mampu meningkatkan pengawasan kinerja manajemen dengan memantau pengambilan keputusan yang dilakukan oleh pihak manajemen sebagai pengelola perusahaan (Wiranata dan Nugrahanti, 2013). Hasil penelitian Chung dan Zhang (2011) menunjukan bahwa investor institusional tertarik pada saham perusahaan yang memiliki struktur tata kelola yang baik dan meminimalkan biaya monitoring. Beberapa peneliti lainnya Mirawati (2013), Munthe (2012), Fazlzadeh, et al (2011) dan Abdurrahman (2008) menyatakan bahwa kepemilikan saham mayoritas oleh perusahaan asuransi, bank, dana pensiun, investment banking akan mendorong peningkatan pengawasan yang lebih optimal.

Cara mengukur rasio kepemilikan institusional adalah dengan membandingkan jumlah lembar saham yang dimiliki institusi terhadap keseluruhan jumlah saham yang beredar.

\section{Struktur Kepemilikan Manajerial}

Agency theory menimbulkan pendapat terhadap adanya konflik pemegang saham dan manajer yang disebabkan adanya perbedaan kepentingan diantara kedua pihak. Potensi konflik kepentingan manajer dan pemegang saham muncul ketika manajer tidak memiliki kepemilikan dalam perusahaan, sedangkan Berle dan Means dalam Gugong, et al., (2014) menegaskan jumlah saham yang dimiliki manajer akan membantu menyelaraskan kepentingan manajer dan pemegang saham. Kepemilikan manajerial dipandang sebagai mekanisme kontrol yang tepat untuk mengurangi konflik tersebut serta mampu menyamakan kepentingan pemilik dan manajer, sehingga semakin tinggi kepemilikan manajerial akan semakin tinggi pula nilai perusahaan (Prasetantyo dan Chariri, 2013).

Pendapat yang sama disampaikan oleh Morck et al., (1998) dan Wahla et al., (2012) bahwa kepemilikan saham manajerial yang tinggi dalam perusahaan dapat bertindak sebagai mekanisme yang mempengaruhi keselarasan kepentingan antara manajer dan pemilik dan akhirnya mempengaruhi nilai pasar perusahaan. Struktur kepemilikan manajerial berpengaruh terhadap kinerja perbankan, semakin tinggi proporsi saham milik manajer semakin baik kinerja perusahaan (Munthe, 2012 dan Ardianingsih dan Ardiyani, 2010). Bahkan Jensen dan Meckling, 1976 menyebutkan bahwa konflik perbedaan kepentingan ini membutuhkan penerapan mekanisme yang dapat melindungi kepentingan pemegang saham dari tindakan oportunis manajer, dan hasil temuannya menyimpulkan bahwa kepemilikan manajerial berhubungan positif terhadap kinerja perusahaan dan berhubungan negatif terhadap biaya keagenan.

Disisi lain, hasil penelitian Wati dan Darmayanti (2013) membuktikan bahwa pemegang saham yang sekaligus bertindak sebagai pengelola perusahaan, tidak mampu memberikan kinerja terbaik mereka. Dewan direksi masih mengutamakan ego atau kepentingan pribadi dibandingkan meningkatkan kinerja yang sekaligus akan meningkatkan nilai perusahaan. Pendapat yang sama telah dikemukakan oleh Wiranata dan Nugrahanti (2013), Mirawati (21013) dan Puspito (2011) bahwa kepemilikan manajerial tidak memberikan pengaruh yang signifikan terhadap kinerja perusahaan.

$$
\text { Agnes (2013) mendefinisikan }
$$

kepemilikan manajerial sebagai jumlah kepemilikan saham oleh pihak manajemen dari seluruh modal saham perusahaan yang dikelola. Persentase kepemilikan manajemen dapat diukur menggunakan insider ownership (INSD), yaitu dengan membandingkan jumlah lembar saham yang dimiliki oleh insider atau manajemen terhadap keseluruhan jumlah saham yang beredar (Agustine, 2014).

\section{Ukuran Perbankan (Size)}

Ukuran perusahaan mencerminkan besar kecilnya perusahaan dinilai dari total aktiva, total penjualan, dan kapitalisasi. Beberapa penelitian merekomendasikan ukuran perusahaan diukur dengan total aktiva karena sifatnya jangka panjang dibandingkan dengan penjualan. Nilai aktiva mencerminkan seberapa 


\section{TRANSPARANSI}

Jurnal Ilmiah Ilmu Administrasi

ISSN 2085-1162

baik kinerja manajer dalam mengelola sumber daya yang dimiliki dan merupakan daya tarik bagi investor untuk menanamkan modalnya pada perusahaan. Ukuran perusahaan akan mempengaruhi peluang perusahaan untuk mengakses pasar modal, semakin besar perusahaan semakin mudah mengakses pasar modal. Hal ini berarti perusahaan besar memiliki fleksibilitas dan kemampuan untuk mendapatkan dana dan memiliki tingkat pengembalian (return) yang lebih besar dibanding perusahaan kecil. Dengan memiliki dana yang banyak, diharapkan perusahaan memiliki peluang untuk mengembangkan usahanya diiringi dengan kinerja perusahaan yang kian membaik. Abdurrahman (2008) menyebutkan bahwa ukuran perusahaan adalah salah satu faktor dominan yang mempengaruhi kinerja perusahaan (ROE) dibandingkan dengan struktur kepemilikan, kesempatan tumbuh, dan komposisi aktiva tetap. Perusahaan besar mempunyai kemampuan untuk membayar tim manajemen yang berkualitas dan berpengalaman. Pembayaran yang tinggi pada manajemen yang berpengalaman dan mempunyai keterampilan tinggi diharapkan dapat mendorong kenaikan kinerja perusahaan.

Ukuran perbankan biasanya diukur menggunakan logaritma natural dari total asset.

\section{Kinerja Perbankan}

Kinerja merupakan pengawasan terus menerus serta pelaporan penyelesaian program, terutama kemajuan pencapaian tujuan yang ditetapkan sebelumnya. Manfaat penilaian kinerja adalah untuk mengetahui efektivitas operasional perusahaan. Kinerja perusahaan dipengaruhi oleh beberapa faktor antara lain terkonsentrasi atau tidak terkonsentrasinya kepemilikan, manipulasi laba, serta pengungkapan laporan keuangan. Kepemilikan yang banyak terkonsentrasi oleh institusi akan memudahkan pengendalian sehingga akan meningkatkan kinerja perusahaan (Windah dan Andono, 2013). Laporan kinerja berguna untuk mengukur seberapa jauh efisiensi dan efektifitas manajer dalam mencapai tujuan
Volume VIII, Nomor 02, September 2016

perusahaan serta memenuhi keinginan pemegang saham. Kenaikan harga saham merupakan salah satu faktor yang mencerminkan baiknya kinerja suatu institusi.

Bank yang mampu memenuhi prudential banking regulation dengan baik berpeluang meningkatkan nilai saham dan jumlah dana ketiganya, menjadi indikator peningkatan kinerja bank yang bersangkutan.

Penelitian ini menggunakan rasio profitabilitas untuk menilai kinerja perbankan dengan proksi Return On Equity. Profitabilitas menilai seberapa efisien manajemen memanfaatkan total aset perusahaan menghasilkan pendapatan. Rasio profitabilitas juga membantu investor luar dalam membuat keputusan investasi (Chen and Hammes, 2004).

Return On Equity menunjukan kemampuan perusahaan dalam menghasilkan laba bersih untuk pengembalian ekuitas pemegang saham. ROE dijadikan dasar pengukuran profitabilitas, tetapi juga mencerminkan tingkat pengembalian yang diharapkan (expected rate of return). ROE yang tinggi menunjukkan baiknya kinerja perusahaan dalam memanfaatkan modal sendiri yang berdampak harga sahamnya meningkat. Selain itu ROE juga dijadikan dasar bagi investor untuk mengukur pertumbuhan profitabilitas dan menilai prospek perusahaan di masa depan. Besarnya laba bersih dibagi jumlah modal sendiri yang dinyatakan dalam persentase menunjukan pengukuran rasio Return On Equity.

\section{METODOLOGI PENELITIAN}

Metode penelitian bersifat kuantitatif dengan tingkat eksplanasi yang bersifat asosiatif kausal. Studi asosiatif kausal bersifat mencari hubungan sebab akibat antara suatu variabel dengan variabel lainnya. Penelitian asosiatif kausal dimaksudkan untuk mencari pengaruh variabel bebas yang terdiri dari struktur kepemilikan dan ukuran (size) perbankan terhadap variabel terikat yaitu kinerja perbankan dengan proksi Return on Equity (ROE).

Populasi dalam penelitian ini adalah 40 perbankan yang terdaftar di Bursa Efek Indonesia (BEI) selama 2009-2014. Teknik 
Henny Ritha, Effect of Cash Dividends, Retained Earnings, Earning per Share....

pengambilan sampel yang digunakan adalah metode purposive sampling yang menggunakan kriteria antara lain perbankan yang menyajikan laporan keuangan tahunan secara lengkap dan konsisten selama 2009-2014, menyajikan informasi tentang struktur kepemilikan perbankan secara lengkap dan terperinci, kepemilikan saham perbankan pernah dimiliki oleh institusi dan manajemen serta nilai aktiva, kewajiban dan ekuitas perbankan positif. Berdasarkan kriteria tersebut maka sampel yang terpilih adalah 6 perbankan yang terdiri dari bank Bukopin Tbk (BBKP), bank Woori Saudara 1906 (SDRA), bank Mayapada Internasional Tbk (MAYA), bank Negara Indonesia Tbk (BBNI), bank Sinarmas Tbk (BSIM) dan bank Tabungan Pensiunan Nasional (BTPN).

Sumber data adalah data sekunder berupa laporan keuangan tahunan periode 2009-2014 yang diperoleh dari situs resmi Bursa Efek Indonesia (www.idx.co.id). Pengujian hipotesis menggunakan metode panel data (Pooled data) yang diolah menggunakan software Eviews 8 dengan mengaplikasikan metode kuadrat terkecil (Ordinary Least Square) pada model efek tetap (Fixed Effect) dan model efek tetap (Fixed Effect) pada model efek acak (Random Effect). Setelah itu dilakukan serangkaian pengujian statistik menggunakan uji Chow dan uji Hausman untuk mendapatkan model yang optimal/ terbaik untuk menjelaskan hasil penelitian ini. Pengujian asumsi model regresi telah dilakukan uji asumsi klasik yang terdiri dari uji normalitas, multikolinieritas, autokorelasi dan heteroskedastisitas dan hasilnya menunjukan model regresi yang digunakan benar-benar menunjukan hubungan yang signifikan dan representative atau disebut BLUE (Best Linier Unbiased Estimator). Analisis model regresi berganda meliputi Uji F, Uji $\mathrm{t}$ dan Koefisien Determinasi. Pengujian asumsi klasik dan hipotesis dilakukan pada tingkat signifikansi 5\%.

Adapun persamaan model data panel teknik OLS adalah,

$\mathrm{ROE}_{\text {it }}=\beta_{0}+\beta_{1} \mathrm{INST}_{\text {it }}+\beta_{2} \mathrm{MNGR}_{\text {it }}+\beta_{3}$ $\mathrm{SIZE}_{\mathrm{it}}+\mu_{\mathrm{it}}$

Keterangan:

$\mathrm{ROE}_{\text {it }}=$ Return On Equity perbankan i pada tahun $\mathrm{t}$

$\beta_{0} \quad=$ Konstanta $\beta_{1, \ldots,} \beta_{\mathrm{n}}=$ Koefisien garis regresi

INST $_{\text {it }}=$ Kepemilikan Institusional perbankan i pada tahun $\mathrm{t}$

MNGR $_{\text {it }}=$ Kepemilikan Manajerial

perbankan i pada tahun $\mathrm{t}$

SIZE $_{\text {it }}=$ Ukuran perbankan i pada tahun $\mathrm{t}$

$\mu_{\mathrm{it}} \quad=$ Standard Error

\section{HASIL DAN PEMBAHASAN}

Setelah dilakukan serangkaian pengujian yang terdiri dari uji Chow, uji Hausman dan uji Lagrange Multiplier maka didapat kesimpulan bahwa terpilih model Common Effect/ OLS sebagai pendekatan yang tepat untuk mengestimasi model regresi data panel.

Adapun persamaan regresi data panel berdasarkan Common Effect Model adalah,

$\mathrm{ROE}=-\mathbf{0 , 4 1 3 8 8 6}+$ Cfe $+\mathbf{0 , 0 0 8 2 2 8}$ INST + 13,06818 MNGR + 0,016640 SIZE

Dari persamaan tersebut dapat dilihat bahwa konstanta bernilai negatif yang berarti apabila semua variabel independen (INST, MNGR dan SIZE) konstan, maka ROE mengalami penurunan sebesar 0,413886, sedangkan dari ketiga variabel independen menunjukan bahwa MNGR memberikan pengaruh utama terhadap ROE yaitu 13,06818, diikuti oleh SIZE yaitu sebesar 0,016640 dan kepemiilikan institusional dengan koefisien regresi sebesar 0,008228. Hal ini menunjukan ketiga variabel independen tersebut memberikan pengaruh positif terhadap Return On Equity (ROE).

\section{Uji Hipotesis}

Berdasarkan tabel hasil uji $\mathrm{F}$ dapat dilihat bahwa nilai statistik F sebesar 20.92201 dengan probabilitas (F-statistic) 0.000000 . Nilai probabilitas lebih kecil dari tingkat signifikansi $(\alpha)=0,05$ menunjukan nilai statistik $\mathrm{F}$ (F hitung) lebih besar dari $\mathrm{F}$ kritisnya, sehingga hipotesis nol dari uji $F$ ditolak, artinya model regresi yang dibentuk dapat digunakan untuk menginterpretasikan pengaruh struktur kepemilikan institusional (INST), struktur kepemilikan manajerial (MNGR), dan ukuran perbankan (SIZE) terhadap kinerja perbankan. Dengan kata lain, semua variabel bebas secara bersama-sama 


\section{TRANSPARANSI}

Jurnal Ilmiah Ilmu Administrasi

ISSN 2085-1162

dapat menjelaskan pengaruhnya terhadap variabel terikat sampai dengan tingkat signifikansi $5 \%$.

Sedangkan berdasarkan hasil uji t dalam model common effect dapat dilihat bahwa nilai probabilitas INST sebesar 0.7766 lebih besar dari $\alpha=0,05$ yang berarti $\mathrm{H}_{0}$ diterima dan $\mathrm{H}_{1}$ ditolak, yaitu kepemilikan institusi tidak berpengaruh signifikan terhadap kinerja perbankan. Hal ini dapat diartikan naik atau turunnya kinerja perbankan tidak tergantung pada besar atau kecilnya struktur kepemilikan institusional, artinya ada dan tanpa adanya struktur kepemilikan tidak menyebabkan perubahan pada kinerja perbankan. Faktor lain yang dapat diduga sebagai penyebab kesimpulan ini adalah relatif kecilnya porsi kepemilikan institusi perbankan, hal ini dapat dilihat pada salah satu bank yaitu bank Bukopin yang sahamnya dimiliki banyak institusi tetapi dengan jumlah kepemilikan proporsi saham yang kecil (sedikit) dan adanya proses penggabungan (Merger) bank Himpunan Saudara 1906 Tbk oleh bank Woori Indonesia pada akhir 2013 menyebabkan kepemilikan institusi bank Saudara sangat kecil yaitu hanya $4,82 \%$. Selain itu tidak semua saham perbankan dimiliki oleh institusi (bank, asuransi, perusahaan investasi, perusahaan efek, dana pensiun, dan lain-lain) juga dapat menyebabkan terbatasnya kesempatan pihak institusi untuk memonitor manajemen dalam operasional perbankan. Sedangkan bila saham dimiliki oleh banyak institusi terutama institusi lain yang tidak ada kaitannya dengan kelompok perbankan itu sendiri maka pengendalian terhadap manajer yang lebih intens, penyalahgunaan informasi serta agency cost perbankan yang berlebihan dapat dihindari, sehingga tujuan peningkatan kinerja perbankan dapat terwujud. Disisi lain adanya pemilik mayoritas institusi seperti Pemerintah yang memegang porsi tertinggi di salah satu bank turut serta dalam pengendalian perbankan, sehingga patut diduga pemilik mayoritas tersebut cenderung bertindak untuk kepentingan mereka sendiri meskipun dengan mengorbankan kepentingan pemilik minoritas (Wiranata dan Nugrahanti, 2013).
Volume VIII, Nomor 02, September 2016

Hasil penelitian ini mendukung pernyataan Al-Najjar (2010) bahwa hanya investor institusional yang besar mempunyai insentif yang signifikan untuk memonitor kinerja manajemen perusahaan. Hasil yang sama telah dikaji oleh Wiranata dan Nugrahanti (2013), Ardianingsih dan Ardiyani (2010) serta Prasetyanto dan Chariri (2013) bahwa tidak semua perusahaan dimiliki oleh institusi, dan dalam kondisi jumlah kepemilikan saham yang sedikit, maka kesempatan institusi mengawasi manajer perusahaan akan terbatas.

Variabel kepemilikan manajerial mempunyai pengaruh positif dan signifikan terhadap kinerja perbankan 2009-2014. Hal ini dapat dilihat dari nilai probabilitas MNGR sebesar 0.0000 yang lebih kecil dari $\alpha=0,05$ sama artinya $t$ hitung ( $\mathrm{t}$ statistik) lebih besar dari $t$ tabel. Temuan ini mendukung pernyataan Jensen dan Meckling (1976) bahwa kepemilikan manajerial akan mendorong manajemen untuk meningkatkan kinerja perusahaan karena mereka juga memiliki perusahaan. Selain itu manajer yang mensejajarkan kepentingannya dengan kepentingan pemegang saham, dinilai mampu membuat perbedaan dalam pencapaian kinerja perusahaan dibandingkan dengan perannya sebagai tenaga profesional. Dengan kata lain, pemegang saham yang sekaligus bertindak sebagai pengelola perusahaan, mampu memberikan kinerja terbaik mereka. Kinerja perbankan yang meningkat akan memberikan signal positif bagi para investor eksternal untuk meningkatkan investasinya. Dengan demikian pernyataan bahwa pihak manajemen dalam menjalankan kegiatan operasionalnya dengan bertindak hanya untuk kepentingannya sendiri adalah tidak terbukti.

Hasil penelitian ini memperkuat penelitian Ardianingsih dan Ardiyani (2010), dan Munthe (2012) bahwa kepemilikan manajerial berpengaruh terhadap kinerja perbankan. Semakin tinggi proporsi saham milik manajer, semakin baik kinerja perbankan.

Ukuran perbankan (size) juga berpengaruh positif dan signifikan terhadap kinerja perbankan 2009-2014, hal ini dapat dilihat dari nilai probabilitas Size 0.0026 yang 


\section{Henny Ritha, Effect of Cash Dividends, Retained Earnings, Earning per Share....}

lebih kecil dari $\alpha=0,05$. Hasil ini menunjukan bahwa jika ukuran perbankan meningkat, maka kinerja perbankan yang diukur dengan profitabilitas (ROE) juga akan meningkat. Sebagai contohnya salah satu bank yaitu Bank Negara Indonesia Tbk (BBNI) merupakan perbankan dengan ukuran terbesar yang ditunjukan dari total asset terbesar diantara bank-bank lainnya. Bank dengan total asset yang besar dapat memberikan informasi yang lebih banyak sehingga akan mengurangi asimetri informasi antara insider dengan investor luar, dan membuat kinerja manajemen lebih mudah dipantau sehingga mengurangi tindakan opportunistik para manajer. Besarnya total asset dapat dijadikan cerminan baiknya kinerja manajemen dalam mengelola sumber daya perbankan. Perbankan besar juga lebih mudah mengakses pasar modal yang berarti bank besar memiliki fleksibilitas dan kemampuan dalam mendapatkan dana untuk mengembangkan usahanya. Bank dengan pendanaan besar juga mampu memperkerjakan tim manajemen yang berkualitas dan berpengalaman yang diharapkan dapat meningkatkan kinerja perbankan. Hasil ini didukung oleh penelitian Munthe (2012), Abdurrahman (2008) dan Munthe (2008). Hasil penelitian ini berbeda dengan temuan Wiranata dan Nugrahanti (2013) dan Mirawati (2013) yang berpendapat besar atau kecilnya perbankan tidak dapat dijadikan jaminan bahwa perbankan tersebut memiliki kinerja yang baik, artinya belum tentu perbankan tersebut mampu mengelola dan memanfaatkan dana itu dengan baik, begitupun sebaliknya.

Ketiga variabel independen (bebas) yang terdiri dari struktur kepemilikan institusional, struktur kepemilikan manajerial, dan ukuran perusahaan memiliki kontribusi sebesar $63,07 \%$, sedangkan sisanya sebesar $36,93 \%$ dipengaruhi oleh faktor lain yang tidak disebutkan dalam penelitian ini misalnya faktor ekonomi, kondisi pasar modal, iklim investasi, peraturan pemerintah, politik, dan lain-lain.

\section{SIMPULAN}

Berdasarkan analisis hasil penelitian maka dapat disimpulkan: 1). Kepemilikan institusional tidak berpengaruh terhadap kinerja perbankan. Relatif kecilnya porsi kepemilikan institusi dan tidak semua perbankan dimiliki oleh institusi menyebabkan proses monitoring dan kontrol terhadap manajer tidak efektif, sehingga kepemilikan institusional dinilai tidak mampu mendorong peningkatan kinerja perbankan. Hasil penelitian ini sesuai dengan pernyataan beberapa temuan sebelumnya bahwa hanya investor institusional yang besar mempunyai insentif yang signifikan untuk memonitor kinerja manajemen perusahaan; 2). Struktur kepemilikan manajerial berpengaruh positif dan signifikan terhadap kinerja perbankan. Hal ini mendukung teori keagenan (Agency Theory) bahwasanya kepemilikan manajerial mampu mengurangi biaya keagenan (Agency cost) dengan cara mendorong penyatuan kepentingan prinsipal dan agen, sehingga manajer bertindak sesuai dengan keinginan pemegang saham. Tim manajemen mampu menunjukan tingkat profesionalisme dalam mengelola sumber daya untuk meningkatkan kinerja perbankan, sehingga adanya anggapan pihak manajemen bertindak hanya untuk kepentingannya sendiri (Opportunistik) adalah tidak terbukti; 3). Ukuran perbankan (Size) memberikan pengaruh positif dan signifikan terhadap kinerja perbankan. Ini menunjukan bank dengan total asset yang besar mampu mengurangi asimetri informasi antara insider dengan investor luar yang membuat kinerja manajemen lebih mudah dipantau sehingga mengurangi tindakan opportunistik para manajer dan mengurangi agency cost. Besarnya total asset dapat dijadikan cerminan baiknya kinerja manajemen karena secara tidak langsung menunjukan tingkat profesionalisme tim manajemen dalam mengelola sumber daya perbankan; dan 4). Struktur kepemilikan institusional, struktur kepemilikan manajerial, dan ukuran perusahaan memiliki kontribusi sebesar 63,07\%, sedangkan sisanya sebesar 36,93\% dipengaruhi oleh faktor lain misalnya faktor ekonomi, kondisi pasar modal, iklim investasi, peraturan pemerintah, politik, dan lain-lain.

\section{REKOMENDASI}

1). Untuk penelitian selanjutnya sebaiknya dapat memperbaiki model penelitian dengan menambah variabel struktur kepemilikan (Asing, Pemerintah dan 


\section{TRANSPARANSI}

Jurnal Ilmiah Ilmu Administrasi

ISSN 2085-1162

masyarakat) dan menambah proksi kinerja perbankan selain ROE, misalnya dengan variabel PER sehingga hasil penelitian lebih tepat dan akurat; 2). Menggunakan periode yang lebih panjang dan memperluas kriteria sampel dengan memasukan perbankan yang memiliki ekuitas positif maupun negatif sehingga jumlah sampel bertambah banyak yang dapat menunjukan keadaan sebenarnya; $3)$. Tersedianya informasi tentang pemegang saham yang lebih rinci, sehingga memudahkan penentuan struktur kepemlikan (institusional, manajerial, pemerintahan, asing, masyarakat, dan lainnya); dan 4). Menetapkan kebijakan batas minimum dan maksimum atas kepemilikan manajerial sehingga kepemilikan saham mencapai jumlah yang proporsional.

\section{DAFTAR PUSTAKA}

Abdurrahman, D. S. (2008). Pengaruh Penerapan GCG dan Struktur Kepemilikan Terhadap Kinerja Perusahaan (Studi Empiris pada Perusahaan LQ 45 Tahun 2001-2005 di BEJ).

Agnes. (2013). Pengaruh Kepemilikan Manajerial, Struktur Modal, dan Ukuran Perusahaan Terhadap Nilai Perusahaan. Padang: Universitas Negeri Padang.

Agustine, I. (2014). Pengaruh Corporate Social Responsibility Terhadap Nilai Perusahaan. Finesta, Vol. 2(1), 42-47.

Al-Matari, E. M., Al-Swidi, A. K., \& Fadzil, F. H. B. (2013). Ownership Structure Characteristics and Firm Performance: A Conceptual Studies. Journal of Sociological Research, Vol. 4(2), 464493.

Ardianingsih, A., dan Ardiyani, K. (2010). Analisis Pengaruh Struktur Kepemilikan Terhadap Kinerja Perusahaan. Jurnal Pena, Vol. 19(2), 97-109.

Al-Najjar, B. (2010). Corporate Governance and Institutional Ownership: evidence from Jordan. Corporate Governance: The international Journal of Business in Society, Vol. 10(2), pp. 176-190.
Volume VIII, Nomor 02, September 2016

Chen, Y., \& Hammes, K. (2004). Capital Structure. Theories and Empirical Results - a Panel Data Analysis. SSRN Electronic Journal.

Chung, K. H; J, Elder; and J, C, Kim. (2010) Corporate Governance and Liquidity. Journal of Financial and Quantitative Analysis, pp. 265-29.

Chung, K. H., \& Zhang, H. (2011). Corporate Governance and Institutional Ownership. Journal of Financial and Quantitative Analysis, Vol. 46 (1). 247-273.

Demsetz, Harold and Villalonga, Belen. (2001). Ownership Structure and Corporate Performance. Journal of Corporate Finance, pp. 209-233.

Fazlzadeh, A., Hendi, A. T., \& Mahboubi, K. (2011). Examination of the Effect of Ownership Structure on Firm Performance in Listed Firms of Tehran Stock Exchange Based on the Type of the Industry. International Journal of Business and Management, Vol. 6(3), 249-266.

Gugong, B. K., Arugu, L. O., \& Dandago, K. I. (2014). The Impact of Ownership Structure on the Finance performance of Listed Insurance Firms in Nigeria. International Journal of Academic Research in Accounting, Finance and Management Sciences, Vol. 4(1), 409416.

Haruman, T. (2008). Pengaruh Struktur Kepemilikan Terhadap Keputusan Keuangan dan Nilai Perusahaan Survey pada Perusahaan Manufaktur di PT. Bursa Efek Indonesia. SNA XI: Ikatan Akuntan Indonesia.

Iavorskyi, M. (2013). The Impact of Capital Structure on Firm Performance: Evidence from Ukraine. Kyiv School of Economics.

Jensen, M. C., \& Meckling, W. H. (1976). Theory of the Firm: Managerial Behaviour, Agency Costs and Ownership Structure. Journal of Financial Economics, October, 1976, V. 3, No. 4, pp. 305-360. 
Henny Ritha, Effect of Cash Dividends, Retained Earnings, Earning per Share....

Kristianto, R. (2010). Pengaruh Struktur Kepemilikan, Struktur Modal, Profitabilitas, dan Ukuran Perusahaan Terhadap Nilai Perusahaan. Surabaya: STIE Perbanas.

Mirawati. (2013). Pengaruh Struktur Kepemilikan dan Ukuran Perusahaan Terhadap Profitabilitas Perusahaan Property dan Real Estate yang Terdaftar di Bursa Efek Indonesia.

Morck, R., A, Shleifer; and R, W, Vishny. (1988). Management Ownership and Market Valuation: An Empirical Analysis. Journal of Financial Economics, pp. 293-315

Munthe, K. (2008). Pengaruh Struktur Kepemilikan, Karakteristik Perusahaan, Tata Kelola Korporasi Terhadap Kinerja Perusahaan Manufaktur di Bursa Efek Indonesia.

Munthe, K. (2012). Pengaruh Struktur Kepemilikan Saham Terhadap Kinerja Perusahaan pada Perusahaan yang Telah Tercatat di Bursa Efek Indonesia.

Prasetyanto, P., \& Chariri, A. (2013). Pengaruh Struktur Kepemilikan dan Kinerja Intellectual Capital Terhadap Nilai Perusahaan. Diponegoro Journal of Accounting, Vol. 2(2), 1-12.

Puspito. (2011). Pengaruh Struktur Kepemilikan Pada Kinerja Perusahaan dengan Struktur Modal Sebagai Pemoderasi (Studi pada Perusahaan Makanan dan Minuman yang Terdaftar di BEI). Riset Manajemen \& Akuntansi, Vol. 2(3), 84-113.

Setiawan, M., Bernik, M., \& Sondari, M. C. (2006). Pengaruh Struktur Kepemilikan, Karakteristik Perusahaan, dan Karakteristik Tata Kelola Korporasi Terhadap Kinerja Perusahaan. Universitas Padjadjaran.

Wahla, K., Shah, S. Z., \& Hussain, Z. (2012). Impact of Ownership Structure on Firm Performance Evidence from NonFinancial Listed Companies at Karachi Stock Exchange. International Research Journal of Finance and Economics Issue 84. 6-13.

Wati, N. A., \& Darmayanti, N. P. (2013). Pengaruh Kepemilikan Manajerial dan
Kinerja Keuangan Terhadap Kebijakan Dividend an Nilai Perusahaan.

Windah, G. C., \& Andono, F. A. (2013). Pengaruh Penerapan Corporate Governance Terhadap Kinerja Keuangan Perusahaan Hasil Survei The Indonesian Institute Perception Governance (IICG) Periode 2008-2011. Jurnal Ilmiah Mahasiswa Universitas Surabaya, Vol. 2(1).

Wiranata, Y. A., \& Nugrahanti, Y. W. (2013). Pengaruh Struktur Kepemilikan Terhadap Profitabilitas Perusahaan Manufaktur di Indonesia. Jurnal Akuntansi \& Keuangan, Vol. 15(1), 15-26.

www.idx.co.id. 